\title{
Analysis of multilocus DNA reveals hybridization in a contact zone between Empidonax flycatchers
}

\author{
Andrew C. Rush, Richard J. Cannings and Darren E. Irwin \\ A. C. Rush (correspondence), Mus. of Vert. Zool., Dept. of Int. Biol., Univ. of California, 3101 Valley Life Sci. Building, Berkeley, CA 94720- \\ 3160, USA. E-mail: arush@berkeley.edu. - R. J. Cannings, S.11, C96, RR1, 1330 Debeck Rd, Naramata, BC V0H 1NO, Canada-D. E. \\ Irwin, Dept. of Zool., Univ. of British Columbia, 6270 Univ. Boulevard, Vancouver, BC, V6T 1Z4, Canada.
}

\begin{abstract}
Contact zones between recently diverged taxa offer unique opportunities to test whether the forms are reproductively isolated and therefore distinct species. The Pacific-slope flycatcher Empidonax difficilis and Cordilleran flycatcher Empidonax occidentalis are closely related taxa that were officially separated into two species in 1989, a treatment that has been controversial due to reports of phenotypically intermediate birds across the southern interior of British Columbia and Alberta. We present the first analysis of molecular variation across this region, in order to determine whether there is genetic introgression between the taxa. Allopatric populations of Pacific-slope and Cordilleran flycatchers belong to distinct mitochondrial clades, and all of the individuals sampled in interior southwestern Canada have the Pacific-slope haplotype. In contrast, variation in nuclear DNA (AFLPs) indicates hybridization between Pacific-slope and Cordilleran flycatchers in this region. We suggest that the discordance between the mitochondrial and nuclear markers most likely results from stochastic loss of Cordilleran mitochondrial haplotype lineages facilitated by asymmetries in mating due to earlier arrival and greater abundance of Pacific-slope flycatchers in the contact zone. The discovery of hybridization between Pacific-slope and Cordilleran flycatchers in southwestern Canada may call into question the decision to split them into two species. On the other hand, allopatric populations are genetically distinct in both mitochondrial and nuclear DNA, and the hybridization might not affect populations outside of the contact zone. This study highlights the importance of employing multiple genetic markers in studies of contact zones between closely related species.
\end{abstract}

Zones of secondary contact have been of great interest to evolutionary biologists because they provide unique opportunities to observe the evolutionary interactions between divergent but related taxa (Barton and Hewitt 1985, Harrison 1993). Speciation occurs due to the evolution of barriers to gene flow between diverging populations. In birds, this is thought to occur most often due to divergence in allopatry (Mayr 1942, Miller 1956, Newton 2003, Coyne and Orr 2004, Price 2008). The boundary between intraspecific population differentiation and speciation is often blurry, however, and genetically distinct cryptic species pairs can be difficult to differentiate phenotypically (e.g., Irwin et al. 2001a, b, Bowie et al. 2004, Toews and Irwin 2008). Even when divergent groups are identified, it is only when they are in geographic contact that their species status can be rigorously tested (Irwin et al. 2001a, b, Cicero 2004, Price 2008).

When divergent taxa meet in secondary contact, a number of outcomes are possible. First, if strong reproductive isolation has evolved in allopatry as an incidental byproduct of natural selection, sexual selection, or genetic drift, the two taxa can remain distinct (Coyne and Orr 2004, Price 2008). Often, however, reproductive barriers are incomplete, and taxa in secondary contact do interbreed to some extent. If reproductive isolating mechanisms are nonexistent, widespread hybridization and introgression leads to neutral diffusion of alleles between the two parental populations (Endler 1977, Barton and Gale 1993). Over time, this may overcome any divergence that has taken place in allopatry and lead to fusion of the two parental gene pools. A third potential outcome is secondary contact with partial reproductive isolation between two taxa. This can lead to the formation of a stable hybrid zone between the two taxa if some form of selection maintains the zone (Barton and Hewitt 1981). Hybridization in secondary contact zones can make the species status of taxa debatable (e.g., Hubbard 1969, Barrowclough 1980, Rising 1996, Cicero and Johnson 1998). Despite creating taxonomic confusion, zones of secondary contact and hybridization provide unique opportunities to examine the factors that contribute to evolutionary divergence and reproductive isolation (Price 2008).

Molecular genetic data can assist in distinguishing between the possible outcomes of secondary contact. If reproductive isolation between two taxa is complete, genetically distinct individuals should coexist in sympatry in a contact zone with no genetically intermediate individuals present. If neutral diffusion of alleles is occurring, a 
gradual, clinal transition in genetic characters will form between the two taxa, with genetically intermediate individuals occurring over a geographic area that increases with time. If a stable hybrid zone has formed, genetically intermediate individuals will be present in a more restricted geographic area between the two parental populations. In this case, two main models describe the types of hybrid zones that may form. In a tension zone (Barton and Hewitt 1981, Barton and Gale 1993), two parental populations are separated by a narrow region in which genetically intermediate individuals occur. This region does not necessarily correspond to or track specific geographic or environmental features. In a selection gradient, the two parental populations occur in distinct environments and genetically intermediate individuals are restricted to an intervening area that is environmentally intermediate between the two parental environments (Moore 1977, Moore and Price 1993). The width and placement of this area is determined by the extent of the intermediate habitat.

Accurate inference of evolutionary dynamics in secondary contact zones generally requires examination of multiple types of genetic evidence (Edwards et al. 2005). The permeability of hybrid zones to different genes may vary due to differences in the strength of selection and demographic effects, and reliance on individual genetic markers to reconstruct species histories (e.g., mitochondrial DNA) can sometimes lead to inaccurate conclusions (Irwin 2002, Ballard and Whitlock 2004, Edwards et al. 2005; but see Zink and Barrowclough 2008). Numerous studies of hybridization between closely related species in disparate groups have shown a lack of geographical concordance between mitochondrial and nuclear markers (e.g., Patton and Smith 1994, Wake and Schneider 1998, Rohwer et al. 2001, Irwin et al. 2005, Ruegg 2007, Good et al. 2008), highlighting the importance of utilizing multiple molecular markers in molecular biogeographic studies.

A particularly intriguing group for the study of speciation is the Empidonax flycatchers (Passeriformes: Tyrannidae), a New World genus of perching birds that are very similar morphologically, but divergent in vocalizations and ecology (Johnson 1963, Stein 1963, Johnson 1980, Johnson and Cicero 2002). Vocalizations are innate in Empidonax flycatchers (Kroodsma 1984, 1985), suggesting that vocal variation should correlate more closely to genotype than it does in birds with learned song (Kroodsma et al. 1995); the presence of individuals with vocalizations intermediate between two Empidonax species has been taken as evidence of hybridization (Johnson 1980, Stein 1963). In general, few hybrids have been reported between Empidonax species (McCarthy 2006), but because such a high level of morphological similarity between species likely makes field identification of hybrids very difficult (Pyle 1997), it is likely that hybrids have been overlooked.

Pacific-slope flycatchers Empidonax difficilis and Cordilleran flycatchers E. occidentalis are sister taxa (Johnson and Cicero 2002), and are estimated to have diverged approximately 350000 years ago (from genetic distances in Johnson and Cicero 2002), using a widely accepted molecular clock for mitochondrial DNA of $2 \%$ sequence divergence per million years (García-Moreno 2004, Lovette 2004, Weir and Schluter 2004, Price 2008, Weir and
Schluter 2008). Throughout most of their ranges, Pacificslope and Cordilleran flycatchers occupy distinct bioclimatic regions. Pacific-slope flycatchers are distributed largely in mesic, temperate coniferous forest west of the crest of the Sierra Nevada and Cascade mountain ranges, and reach their highest densities along the Pacific Northwest coast of the United States and Canada (Johnson 1980, Lowther 2000; Fig. 1). Cordilleran flycatchers are distributed at higher elevations in cooler, more xeric coniferous forest in the interior mountain West from central Mexico to the northern Rocky Mountains, and reach their highest densities much farther south in the southern Rocky Mountains (Johnson 1980, Lowther 2000).

Pacific-slope Empidonax difficilis and Cordilleran flycatchers E. occidentalis were formerly classified as subspecies of a single species, the "western flycatcher," but were elevated to species status based on differences in vocal, morphological, and allozyme characters (Johnson and Marten 1988, American Ornithologists' Union 1989, Johnson 1994). This was based on the work of Johnson (1980, 1994), and Johnson and Marten (1988), who maintained that the only confirmed area of sympatry between the two forms was in the Siskiyou Mountains in northeastern California and that the two taxa were reproductively isolated there. Largely excluded from earlier analyses were "western flycatcher" populations from interior southwestern Canada. Subsequent observations have suggested that many flycatchers in parts of this region have vocal features that are intermediate between Pacific-slope and Cordilleran types, leading observers to suspect hybridization between the two forms in this region and to question their taxonomic status (Fig. 1; Campbell et al. 1997, Kulba and McGillivray 2000, Lowther 2000, Marshall et al. 2003, Wahl et al. 2005). There is a consensus that populations west of the Cascade and Coast mountain ranges are Pacific-slope, but sources differ on whether interior populations are comprised of non-overlapping populations of Pacific-slope and Cordilleran flycatchers, the two forms living in sympatry, or a hybrid swarm (Campbell et al. 1997, Kulba and McGillivray 2000, Lowther 2000, Marshall et al. 2003, Wahl et al. 2005). Until now, formal analyses of these populations have been lacking.

Here, we provide the first genetic analysis of Pacificslope and Cordilleran flycatchers in southwestern Canada, comparing them with samples from allopatric areas. We conduct phylogenetic analysis of mitochondrial DNA, and Bayesian admixture analysis of multilocus nuclear DNA, as surveyed using amplified fragment length polymporphisms (AFLPs; Vos et al. 1995, Campbell et al. 2003, Bensch and Åkesson 2005). AFLPs have been shown in previous studies to be effective in elucidating population structure between weakly differentiated taxa (Wang et al. 2003, Bensch and Åkesson 2005, Irwin et al. 2005, Vallender et al. 2007). We test whether populations of "western flycatchers" in interior southwestern Canada consist of: (1) just one of the Pacificslope or Cordilleran flycatcher species, (2) members of both species, with no evidence of hybrids, indicating reproductive isolation, or (3) a range of genetically intermediate individuals, indicating hybridization. 


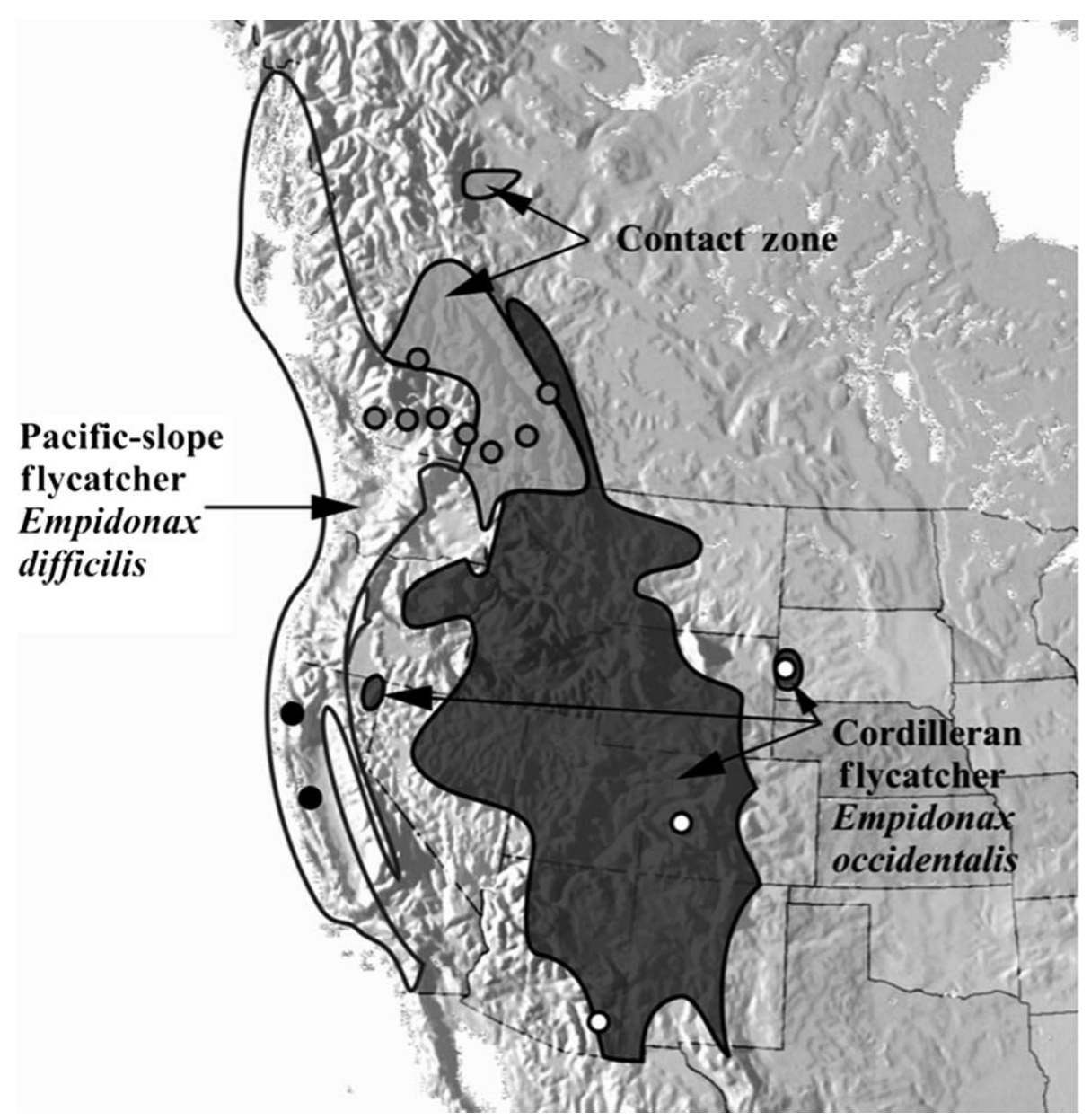

Figure 1. Geographic ranges of Pacific-slope and Cordilleran flycatchers in western North America, based on the map by Lowther (2000). The lighter gray shading shows the area of the interior Pacific Northwest where intermediate vocalizations have been reported. Small circles show the locations of samples used in this study. Black circles are the Pacific-slope reference samples, white circles are the Cordilleran reference samples, and light gray circles are the contact zone samples.

\section{Methods}

\section{Study area}

Field research was conducted in southern and central British Columbia (BC) and southwestern Alberta, Canada. We chose this area because in a preliminary study, one of us (RJC unpubl. data) had found numerous individuals in this area with vocalizations sounding intermediate between Pacific-slope and Cordilleran flycatchers, suggesting that this may be a hybrid zone. Southwestern Canada is varied in physical geography, climate, and vegetation, and includes several biogeographically distinct regions (Parish et al. 1996). The Cascade and Coast mountain ranges (hereafter "Cascades") run northwest to southeast and separate the more mesic coastal forests from the more xeric interior. The xeric southern interior of $\mathrm{BC}$ is comprised of the Okanagan and Thompson Plateaus and the Okanagan Basin and includes some of the driest areas in Canada. East of the Okanagan, the Columbia Mountains contain more mesic forests. East of the Columbia Mountains, the Rocky Mountains are again more xeric but not to the level of central interior BC (Parish et al. 1996). We sampled Pacific-slope/Cordilleran flycatcher populations at eight sites representing each of these regions, from the Pacific coast of $\mathrm{BC}$ to the eastern slope of the Rocky Mountains in western Alberta (Table 1).

\section{Collections, DNA amplification, and sequencing}

We captured flycatchers in mist nets and took a blood sample $(5-20 \mu \mathrm{l})$ from the brachial vein of each bird before releasing it. We targeted territorial males on breeding territories. Blood was stored in $500 \mu \mathrm{l}$ of "Queen's lysis buffer" (0.01 M Tris, $0.01 \mathrm{M} \mathrm{NaCl}, 0.01 \mathrm{M}$ EDTA, and $1 \% n$-lauroylsarcosine, $\mathrm{pH}$ 7.5; Seutin et al. 1991). Extracted DNA was stored in $100 \mu \mathrm{l}$ of $1 \mathrm{X}$ TE $(10 \mathrm{mM}$ Tris-HCl, $1 \mathrm{mM}$ EDTA, pH 8.0) and stored at $4^{\circ} \mathrm{C}$ in the lab. Tissue samples of allopatric populations of Pacific-slope and Cordilleran flycatchers were provided by the Mus. of Vert. Zool. at the Univ. of California, Berkeley and used as reference samples of the two species. Reference samples from California were collected outside of any area of suspected sympatry between the two species. Reference individuals were determined to be in breeding condition based on the date of collection and gonad size. Whole genomic DNA was extracted from all samples using a standard phenol-chloroform method. We used two methods 
Table 1. Sampling locations including total numbers of individuals used from each site as well as the numbers used in each type of analysis. Taxonomic status of individuals is assigned as Pacific-slope or Cordilleran if from allopatric populations of these species, but as 'contact zone' (i.e., unknown) if from the study area in Canada. 'MVZ' indicates the Museum of Vertebrate Zoology; 'RCI' indicates Rush, Cannings, and Irwin (this study).

\begin{tabular}{|c|c|c|c|c|c|c|c|c|}
\hline Taxon & Site & State/Province & Lat. ${ }^{\circ} \mathrm{N}$ & Long. ${ }^{\circ} \mathrm{W}$ & Sample source & Sample size & ND2 & AFLP \\
\hline Pacific-slope & Lake Co. & California & 39.38 & 122.87 & MVZ & 1 & 1 & 1 \\
\hline Pacific-slope & Monterey Co. & California & 36.33 & 121.53 & MVZ & 7 & 7 & 6 \\
\hline Pacific-slope & San Benito Co. & California & 36.38 & 120.64 & MVZ & 2 & 2 & 2 \\
\hline Contact zone & Vancouver & British Columbia & 49.27 & 123.23 & $\mathrm{RCl}$ & 2 & - & 2 \\
\hline Contact zone & Hope & British Columbia & 49.16 & 121.33 & $\mathrm{RCl}$ & 3 & 3 & 3 \\
\hline Contact zone & Williams Lake & British Columbia & 52.11 & 122.04 & $\mathrm{RCl}$ & 4 & 3 & 4 \\
\hline Contact zone & Princeton & British Columbia & 49.57 & 120.50 & $\mathrm{RCl}$ & 4 & 3 & 4 \\
\hline Contact zone & Okanagan & British Columbia & 49.34 & 119.74 & $\mathrm{RCl}$ & 4 & 2 & 4 \\
\hline Contact zone & Christina Lake & British Columbia & 49.07 & 118.19 & $\mathrm{RCl}$ & 5 & 5 & 5 \\
\hline Contact zone & Kootenay Lake & British Columbia & 49.51 & 116.79 & $\mathrm{RCl}$ & 3 & 2 & 3 \\
\hline Contact zone & Kananaskis & Alberta & 51.03 & 115.01 & $\mathrm{RCl}$ & 6 & 6 & 4 \\
\hline Cordilleran & Apache Co. & Arizona & 33.85 & 109.31 & $M V Z$ & 5 & 4 & 4 \\
\hline Cordilleran & Graham Co. & Arizona & 32.63 & 109.82 & MVZ & 2 & 2 & 1 \\
\hline Cordilleran & Custer Co. & Colorado & 38.05 & 105.05 & MVZ & 5 & 5 & 4 \\
\hline Cordilleran & Lawrence Co. & South Dakota & 44.16 & 103.88 & MVZ & 1 & 1 & 1 \\
\hline Total & & & & & & 54 & 46 & 48 \\
\hline
\end{tabular}

of DNA analysis, but due to problems with amplification for some individuals, the set of individuals for each analysis differs slightly (Table 1).

We amplified the entire 1,041-base pair mitochondrial gene ND2 in 10 allopatric Pacific-slope flycatchers, 12 allopatric Cordilleran flycatchers, and 24 Canadian individuals (Table 1) using the primers H1064 (Drovetski et al. 2004) and L5215 (Hackett 1996), and the following thermocycler protocol: $3 \mathrm{~min}$ at $95^{\circ} \mathrm{C}, 35$ cycles of $95^{\circ} \mathrm{C}$ $(30 \mathrm{~s}), 55^{\circ} \mathrm{C}(30 \mathrm{~s})$, and $72^{\circ} \mathrm{C}(30 \mathrm{~s})$, followed by a final extension of $72^{\circ} \mathrm{C}$ for $10 \mathrm{~min}$. ND2 sequences were edited using the program Sequencher (Genecodes Corporation) and aligned using the programs CLC Free Workbench 4 (http://www.clcbio.com), and MacClade 4.06 OS X (Maddison and Maddison 2003). After uneven ends were trimmed from the sequences, we analyzed a 932-base pair segment of the gene. Sequences can be downloaded from Genbank.

To examine variation in the nuclear genome, we used the amplified fragment length polymorphism (AFLP) method according to the protocol of LI-COR Biosciences (2003), based on the method developed by Vos et al. (1995). Whole genomic DNA was digested with the endonucleases $E c o$ RI and $M s e \mathrm{I}$ and then ligated to $\mathrm{E}$ - and M-adaptors (100 nM). We preamplified DNA fragments using complimentary $\mathrm{E}$ - and M-primers and then selectively amplified a subset of DNA fragments using 5 primer combinations (Table 2). We used a LI-COR 4300 to separate DNA bands in a $6.5 \%$ polyacrylamide gel and scored bands as present or absent using the program SAGA version 2.0. We generated 127

Table 2. AFLP primer combinations and number of polymorphic fragments generated by each primer combination.

\begin{tabular}{lccc}
\hline $\begin{array}{l}\text { Primer } \\
\text { combination }\end{array}$ & $\begin{array}{c}\text { EcoRI-primer } \\
(\text { NNN-3') }\end{array}$ & $\begin{array}{c}\text { Trul-primer } \\
(\text { NNN-3 })\end{array}$ & $\begin{array}{c}\text { No. of polymorphic } \\
\text { fragments }\end{array}$ \\
\hline 1 & ACA & CAC & 26 \\
2 & ACT & CAC & 44 \\
3 & AGC & CAT & 9 \\
4 & AGG & CAC & 22 \\
5 & ACC & CAC & 26 \\
\hline
\end{tabular}

polymorphic bands that we were able to score unambiguously in 48 individuals (Table 2).

\section{Data analysis}

To test for evidence of directional selection on the ND2 gene, we used DnaSP to calculate Tajima's D and to perform a McDonald and Kreitman test on the Cordilleran and Pacific-slope reference samples (Rozas et al. 2003). Significant results for the Tajima's D test can indicate either selection or population expansion; the McDonald and Kreitman test is less sensitive to the effects of population expansion (McDonald and Kreitman 1991). To further test for a population expansion, we used DnaSP to perform Fu's $\mathrm{F}_{\mathrm{s}}$ tests, which are more sensitive to population expansion than Tajima's D (Fu 1997). To look for evidence of population structure in mitochondrial DNA, we created a statistical parsimony haplotype network from the ND2 sequences using the program TCS v1.21 (Clement et al. 2000).

We summarized the variation in the AFLP profiles of individuals with principal components analysis (PCA), using the software package $\mathrm{R}$ ( $\mathrm{R}$ Development Core Team 2006, Toews and Irwin 2008).

To quantify population differentiation among sites, we used the program Arlequin 3.1 (Excoffier et al. 2005) to calculate population pairwise $\mathrm{F}_{\mathrm{ST}}$ values from AFLP data. Some geographically proximate sites were grouped a priori to increase group size (Vancouver and Hope were combined and all California samples were combined). AFLP profiles were coded as binary ( 0 or 1 ) haplotypic RFLP data and significance was calculated from 1.023 permutations. Although $\mathrm{F}_{\mathrm{ST}}$ values calculated from these data provide useful measures of genetic differentiation between populations, they are not calculated from allele frequencies and cannot be compared directly to $\mathrm{F}_{\mathrm{ST}}$ values calculated from codominant markers.

We used the program STRUCTURE V2.2 (Pritchard et al. 2000, Falush et al. 2007) to group samples into populations and to assess levels of gene flow between populations based on AFLP profiles. STRUCTURE uses a 


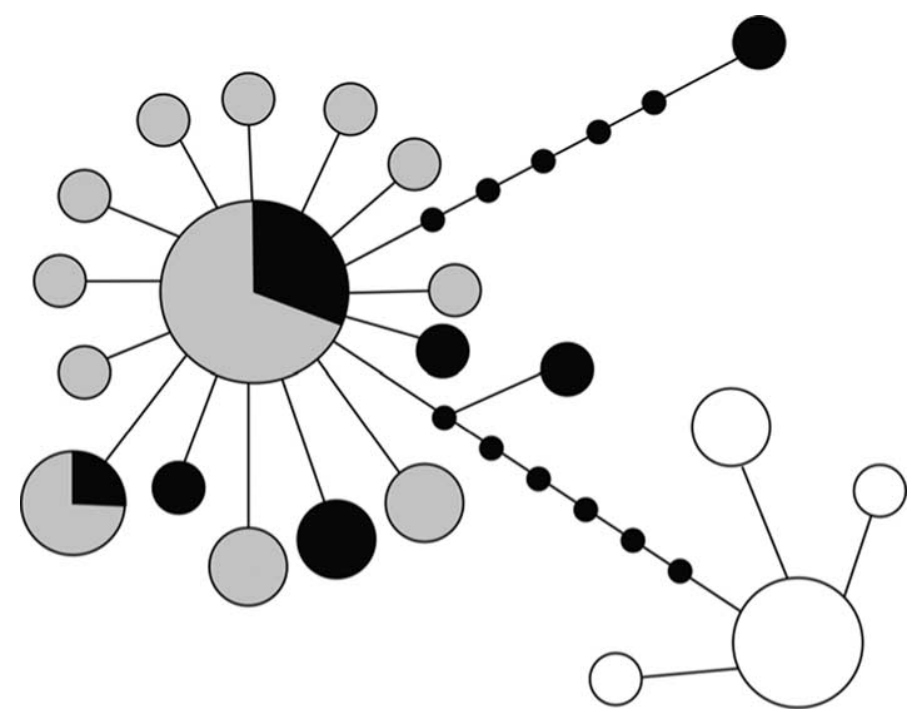

Figure 2. ND2 haplotype network. Black represents Pacific-slope flycatcher reference samples, white represents Cordilleran flycatcher reference samples, and gray represents Canadian samples. Circle areas are proportional to numbers of individuals. Small black circles on connecting lines indicate additional base substitutions (when greater than one).

Bayesian model-based clustering method to infer population structure and to assign individuals probabilistically to a set of populations (k) based on allele frequencies across loci. We used STRUCTURE to estimate $\mathrm{k}$ given no a priori population information. Based on the estimated posterior probability for each run for each value of $k$, STRUCTURE estimates the likelihood of the data. The correct number of populations was taken as the one for which the value of $\mathrm{k}$ had the greatest estimated likelihood. STRUCTURE calculates a membership coefficient (q), defined as the proportion of the genotype of an individual that originated from a given population, and assigns individuals to one or more of the $\mathrm{k}$ populations based on the highest proportion of membership. We performed 5 independent runs of 1.000.000 MCMC repetitions with a burn-in period of 50.000 for each of $\mathrm{k}=1$ through $\mathrm{k}=5$ assuming correlated allele frequencies and a population admixture model. We also used STRUCTURE to calculate the proportion of membership in each of the 2 clusters for 10 pre-defined populations (the eight Canadian sample sites plus the Pacific-slope and Cordilleran reference samples) to assess the level of population admixture among sample sites.

To provide an independent assessment of the genetic ancestry of individuals, we performed an admixture analysis of the AFLP data using the program BAPS 5.2 (Corander and Marttinen 2006, Corander et al. 2008). Similarly to STRUCTURE, BAPS infers population structure among samples using Bayesian clustering methods, although BAPS uses a somewhat different computational approach. Both have the potential to classify individuals as genetically admixed.

\section{Results}

\section{Mitochondrial DNA analysis}

ND2 analysis revealed two main haplotype clusters, one containing allopatric Cordilleran flycatchers and the other containing allopatric Pacific-slope flycatchers as well as all individuals sampled in Canada (Fig. 2). The most common haplotypes of these two clusters differed by six changes, all synonymous $(0.64 \%$ sequence divergence). We detected several rare haplotypes that differed from the main haplotype groups by a small number of changes. There was a greater number of these rare haplotypes in the Pacificslope cluster, but this could reflect the larger number of Pacific-slope haplotypes sampled. A single more divergent haplotype (separated by five mutational changes) is present in the Pacific-slope cluster. This individual was one of seven individuals sampled in Monterey County in central California (Table 1), indicating that it represents a rare haplotype rather than an under-sampled divergent population. The Tajima's D test was not significant for the Cordilleran reference samples $(-1.10317 ; \quad \mathrm{P}>0.10)$, but was significant for the Pacific-slope reference samples $(-1.76515$; $\mathrm{P}<0.05)$. The McDonald and Kreitman test was not significant (two-tailed Fisher's exact test: $\mathrm{P}=0.56$ ), but this test examined only whether there is support for directional selection on sites within the ND2 gene; it would not detect selection operating elsewhere in the mtDNA. Because the entire mitochondrial genome is inherited as a single unit, selection on any part of it will affect phylogeographic patterns observed on all other parts. The Fu's $\mathrm{F}_{\mathrm{s}}$ test was not significant for either the Pacific-slope $(-0.823$, $\mathrm{P}=0.200)$, or the Cordilleran $(-1.410, \mathrm{P}=0.136)$ reference samples.

\section{AFLP analysis}

Each individual had a unique AFLP profile. Principal components analysis separated allopatric Pacific-slope and Cordilleran flycatchers into two widely separated clusters (Fig. 3), although no markers showed fixed differences between Pacific-slope and Cordilleran flycatcher reference samples. The first two principal components explained relatively little of the variation among individuals ( $\mathrm{PC} 1$ : 6.7\%; PC2: $5.2 \%$ ), indicating that the clear separation 


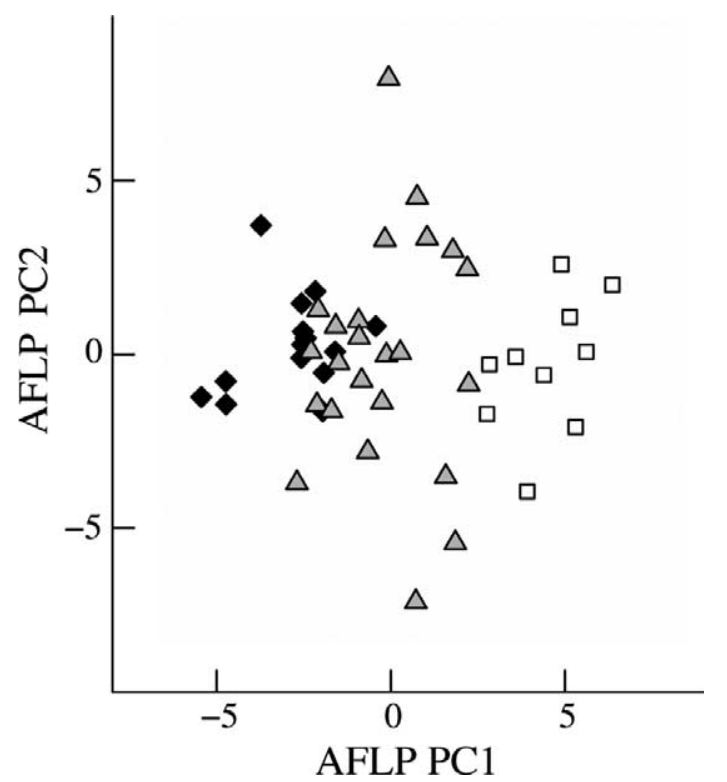

Figure 3. PCA of individuals based on AFLP profiles. Black diamonds represent Pacific-slope flycatchers from California and coastal BC (west of the Cascades), white squares represent Cordilleran flycatchers, and grey triangles represent Canadian samples from interior British Columbia and Alberta.

arose from a relatively weak signal in the genome. Thirty eigenvalues each explained more than $1 \%$, and cumulatively explained $86 \%$ of the genetic variation. The individuals from interior southwestern Canada formed a more diffuse cluster centered between the allopatric Pacific-slope and allopatric Cordilleran clusters. Some of these interior Canadian samples occurred within the Pacific-slope cluster, but most occurred between the Pacific-slope and Cordilleran clusters, indicating the genetic intermediacy of these individuals. A small number of the Canadian samples bordered the Cordilleran cluster, but none fell within it.

Despite relatively small sample sizes in some cases, more than $50 \%$ of the pairwise $\mathrm{F}_{\mathrm{ST}}$ comparisons of individual sites were significant at the $\mathrm{P} \leq 0.05$ level (Table 3). Most sites showed little differentiation in $\mathrm{F}_{\mathrm{ST}}\left(\mathrm{F}_{\mathrm{ST}}\right.$ ca 0.07$)$ from their nearest neighbors. Canadian coastal samples (e.g. west of the Cascade Mountains, "Vancouver-Hope" in Table 3) and the Pacific-slope reference samples were nearly equally differentiated in $\mathrm{F}_{\mathrm{ST}}$ from the Cordilleran reference samples $\left(\mathrm{F}_{\mathrm{ST}}=0.24, \mathrm{~F}_{\mathrm{ST}}=0.27\right.$ respectively, $\mathrm{P}<0.001$ for both). Cordilleran populations from Colorado and Arizona showed little differentiation from each other $\left(\mathrm{F}_{\mathrm{ST}}=0.07\right.$;
$\mathrm{P}<0.001)$. Princeton, on the eastern slope of the Cascades, showed low differentiation $\left(\mathrm{F}_{\mathrm{ST}}=0.06 ; \mathrm{P}<0.001\right)$ from the Pacific-slope reference samples, but moderate differentiation from the Cordilleran reference samples (avg. $\left.\mathrm{F}_{\mathrm{ST}}=0.15, \mathrm{P}<0.001\right)$. Other sites east of the Cascades in interior $\mathrm{BC}$ showed intermediate levels of differentiation from both the Pacific-slope $\left(\mathrm{F}_{\mathrm{ST}}=0.09-0.17 ; \mathrm{P}<0.001\right)$ and Cordilleran $\left(\mathrm{F}_{\mathrm{ST}}=0.12-0.19 ; \mathrm{P}<0.001\right)$ reference samples. Kananaskis, on the east slope of the Rocky Mountains, showed very little differentiation $\left(\mathrm{F}_{\mathrm{ST}}=0.07\right.$; $\mathrm{P}<0.001$ ) from the Cordilleran reference populations (the comparison between Kananaskis and the Pacific-slope reference populations was not significant).

Based on likelihood values, STRUCTURE indicated that the samples were drawn from two populations (highest $\log$ likelihood $=-3706.68$ ). Pacific-slope and Cordilleran reference samples were assigned to different clusters with a high posterior probability $(\mathrm{q} \geq 0.90$; Fig. 4$)$. We used this $q \geq 0.90$ threshold to classify Canadian individuals of unknown taxonomic status as pure types of either species. The majority of Canadian individuals (18 of 29, 62\%) showed evidence of admixture in their nuclear DNA and were not assigned with $\geq 0.90$ probability to the Pacificslope or Cordilleran cluster (Fig. 4). Of the remaining 11 (38\%), 10 Canadian individuals were classified as pure Pacific-slope while only one was classified as pure Cordilleran. All five individuals sampled west of the Cascades were classified as pure Pacific-slope. East of the Cascades in interior BC and Alberta, only five of the 24 (21\%) individuals sampled could be classified as pure types of either species (4 Pacific-slope, 1 Cordilleran). No individuals showed the roughly even $0.50 / 0.50$ membership in both clusters expected for F1 hybrids, although several were close (e.g. a 0.60/0.40 probability; Fig. 4).

Based on the proportion of ancestry per sample site calculated by STRUCTURE, all sample sites from the Pacific coast to the eastern slope of the Cascades were classified as pure Pacific-slope (Table 4). In southernmost $\mathrm{BC}$, the proportion of ancestry per site changed clinally from the Pacific coast to Kootenay Lake, with the highest level of Cordilleran ancestry evident in populations in south-central BC. Two neighboring sites in south-central BC (Christina Lake and Kootenay Lake) were majority Cordilleran, with no pure parental types of either species present (all other sample sites were majority Pacific-slope). The largest difference in ancestry between two neighboring sites was between Okanagan and Princeton, where proportion of Cordilleran ancestry dropped from 0.44 to 0.09 over

Table 3. Pairwise $\mathrm{F}_{\mathrm{ST}}$ values between all sample sites calculated from AFLP data by Arlequin. Values in bold italics are significantly different from zero $(\mathrm{P} \leq 0.05)$.

\begin{tabular}{|c|c|c|c|c|c|c|c|c|c|c|}
\hline & 1) & 2) & 3) & 4) & 5) & 6) & 7) & 8) & 9) & 10) \\
\hline 1) Vancouver-Hope & 0.00 & & & & & & & & & \\
\hline 2) Princeton & 0.04 & 0.00 & & & & & & & & \\
\hline 3) Williams Lake & 0.10 & 0.00 & 0.00 & & & & & & & \\
\hline 4) Okanagan & 0.03 & 0.00 & 0.01 & 0.00 & & & & & & \\
\hline 5) Christina Lake & 0.07 & 0.07 & 0.10 & -0.02 & 0.00 & & & & & \\
\hline 6) Kootenay Lake & 0.11 & 0.02 & 0.07 & 0.02 & 0.07 & 0.00 & & & & \\
\hline 7) Kananaskis & 0.02 & -0.04 & -0.04 & -0.05 & -0.01 & -0.06 & 0.00 & & & \\
\hline 8) California (Pacific-slope) & 0.08 & 0.06 & 0.17 & 0.09 & 0.13 & 0.15 & 0.03 & 0.00 & & \\
\hline 9) Colorado (Cordilleran) & 0.24 & 0.13 & 0.13 & 0.12 & 0.19 & 0.15 & 0.06 & 0.27 & 0.00 & \\
\hline 10) Arizona (Cordilleran) & 0.23 & 0.16 & 0.15 & 0.12 & 0.11 & 0.14 & 0.08 & 0.27 & 0.07 & 0.00 \\
\hline
\end{tabular}



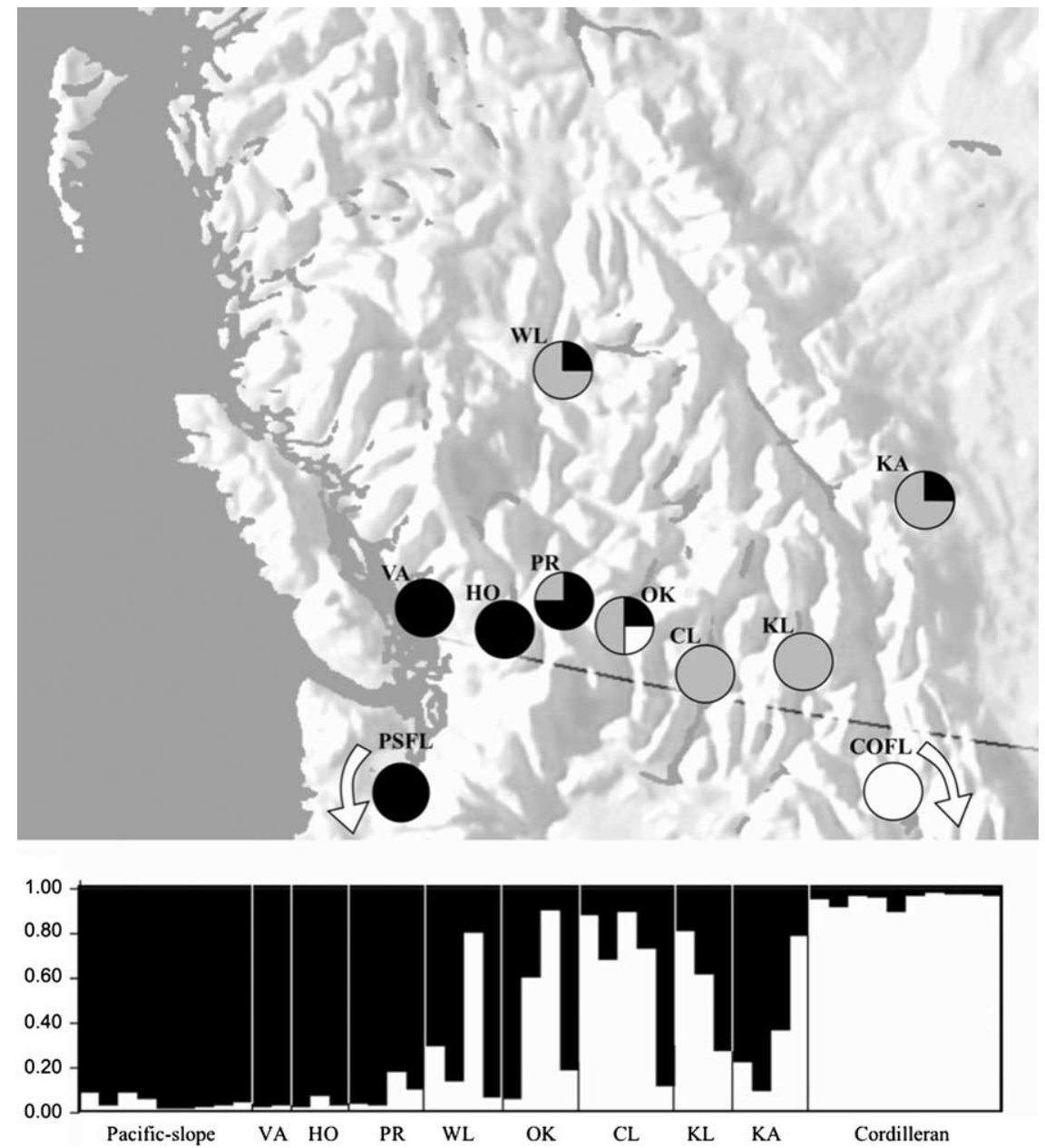

Figure 4. Map of sampling sites in British Columbia and Alberta, Canada and population assignments performed by the program STRUCTURE. In lower graph, each bar represents the proportion of ancestry of a given individual in a population with black corresponding to Pacific-slope and white to Cordilleran. Bars are grouped by sample site and arranged roughly west to east. Individuals labeled "Pacific-slope" (PSFL) are from California and individuals labeled Cordilleran (COFL) are from Colorado, Arizona, and South Dakota. Pie graphs in the top figure show the proportion of individuals per site that belong to the categories Pacific-slope (black), Cordilleran (white), and genetically admixed (gray). Location abbreviations: VA $=$ Vancouver, $\mathrm{HO}=\mathrm{Hope}, \mathrm{PR}=\mathrm{Princeton}, \mathrm{WL}=$ Williams Lake, $\mathrm{OK}=$ Okanagan, $\mathrm{CL}=$ Christina Lake, $\mathrm{KL}=$ Kootenay Lake, $\mathrm{KA}=$ Kananaskis.

approximately $60 \mathrm{~km}$. Williams Lake and Kananaskis are east of the Cascades but north of the southernmost sites, and had proportionately less Cordilleran ancestry than the southernmost sites (Williams Lake $=0.33$ Cordilleran, Kananaskis $=0.37$ Cordilleran).

Results from BAPS confirmed the results from STRUCTURE. As expected, slight differences existed between the two analyses in the assignment of particular individuals to populations, but the key results remain unchanged. BAPS attributed many of the admixed individuals more evenly to the two parental populations than Structure, making them appear more like F1 hybrids than backcrosses. There were five minor discrepancies between the two analyses in terms of assignment to the parental or admixed categories. One individual that was classified as admixed by Structure was classified as pure Pacific-slope by BAPS. The one Canadian individual that was classified as pure Cordilleran by Structure was classified as admixed by BAPS. Three individuals that were classified as pure (i.e. $>0.90$ ) Pacific-slope by Structure were classified as admixed by BAPS. One of these three was from west of the Cascades (from
Vancouver). Of the two analyses, the STRUCTURE results are more similar to the PCA results, and the Vancouver individual falls well within the Pacific-slope cluster in the PCA analysis. Because sites west of the Cascades also show a clear affinity with the Pacific-slope reference samples in the $\mathrm{F}_{S \mathrm{~T}}$ tests, we conclude that they can be treated as Pacificslope. Because the results from STRUCTURE and BAPS were otherwise so similar, we report only the STRUCTURE results in detail (Table 4, Fig. 4).

\section{Discussion}

Analysis of AFLPs and ND2 sequences shows that allopatric populations of Pacific-slope and Cordilleran flycatchers can be differentiated unambiguously using either nuclear or mitochondrial DNA. The $0.64 \%$ divergence in ND2 sequences between Pacific-slope and Cordilleran flycatchers is consistent with the $0.7 \%$ sequence divergence reported by Johnson and Cicero (2002) based on four mitochondrial genes, and our analysis of nuclear DNA provides the first 
Table 4. Proportion of Pacific-slope or Cordilleran ancestry calculated as the combined $q$ values of individuals per sampling site by the program STRUCTURE.

\begin{tabular}{lcc}
\hline Site & $\begin{array}{c}\text { Proportion } \\
\text { Pacific-slope }\end{array}$ & $\begin{array}{c}\text { Proportion } \\
\text { Cordilleran }\end{array}$ \\
\hline Pacific-slope reference samples & 0.95 & 0.05 \\
Vancouver & 0.97 & 0.03 \\
Hope & 0.96 & 0.05 \\
Princeton & 0.91 & 0.09 \\
Williams Lake & 0.67 & 0.33 \\
Okanagan & 0.56 & 0.44 \\
Christina Lake & 0.34 & 0.66 \\
Kootenay Lake & 0.43 & 0.57 \\
Kananaskis & 0.63 & 0.37 \\
Cordilleran reference samples & 0.04 & 0.96 \\
\hline
\end{tabular}

genome-wide measure of genetic differentiation between these two taxa. West of the Cascades, flycatcher populations are genetically similar to allopatric Pacific-slope reference samples, but the species identity of populations in interior $\mathrm{BC}$ and in Alberta is much more ambiguous. The level of genetic intermediacy in these populations strongly suggests that Pacific-slope and Cordilleran flycatchers interbreed in sympatry and that there is a broad area of hybridization between them in this region.

Analysis of AFLPs revealed a clinal transition in the nuclear DNA of these two species in our population admixture analysis, and genetic intermediacy in our $\mathrm{F}_{S T}$ analysis, thus offering a different view of their evolutionary history and species status. Birds of mixed ancestry are present in an area at least $400 \mathrm{~km}$ in width from the eastern slope of the Cascades in $\mathrm{BC}$ to the eastern slope of the Rocky Mountains in Alberta (Fig. 4). The Okanagan site, with roughly even proportions of Pacific-slope and Cordilleran ancestry, may form the center of a genetic transition between these two species. Christina Lake and Kootenay Lake seem to be hybrid swarms, with only admixed individuals present. It is likely that the cline of steadily increasing Cordilleran nuclear DNA continues to the southeast of Christina Lake where densities of Cordilleran flycatchers are likely higher (Lowther 2000). There is a higher level of Cordilleran ancestry at Williams Lake than at some of the sites further south (e.g., Princeton, Table 4). Because the Cascades run diagonally from northwest to southeast, Williams Lake, although west of Princeton, falls farther to the east of the Cascades, in an area somewhat intermediate in vegetation between the mesic coastal and xeric interior forests (Campbell et al. 1997), so an additional possibility is that the higher level of Cordilleran ancestry at this site may reflect greater suitability of the habitat to that species.

The pattern of genetic intermediacy displayed in nuclear DNA contrasts with the pattern in mtDNA, in which all Canadian samples grouped closely with allopatric Pacificslope samples. Discordance between nuclear and mitochondrial DNA highlights the utility of employing multiple genetic markers in phylogeographic studies of closely related taxa. The discordance could arise for a number of reasons. First, if the Pacific-slope haplotype were under positive selection, a selective sweep on the Pacific-slope mitochondrial haplotype could have fixed that haplotype in the Canadian population. However, there is little evidence in support of selection. Although the Tajima's D test was significant for the Pacific-slope reference samples, indicating the possibility of directional selection on the gene or a population expansion, these conclusions were not supported by the McDonald and Kreitman or Fu's Fs tests respectively.

We find it more likely that the discordance between nuclear and mitochondrial DNA is due to asymmetries in mating coupled with demographic effects. Coastal British Columbian populations of Pacific-slope flycatchers are at high densities (Johnson 1980, Campbell et al. 1997), and arrive from their wintering grounds almost a month earlier than interior populations (Campbell et al. 1997). Cordilleran flycatchers are at the northern limit of their range in this region and are likely at lower densities than Pacificslope flycatchers. If some coastal (i.e., Pacific-slope) birds disperse to the interior earlier, either by crossing through passes in the Cascades or by moving northward to the interior via river valleys such as the Okanagan Valley, they could be in the region already when the later migrating Cordilleran flycatchers arrive. There is evidence for earlier arrival of males in populations of Pacific-slope flycatchers on the Queen Charlotte Islands, off the coast of British Columbia (Ainsley 1992). If Cordilleran males arrive earlier than females, they would encounter only Pacific-slope females upon arrival on the breeding grounds in the interior, and as a result, most hybrid offspring would have Pacific-slope mitochondrial haplotypes, whereas half of their nuclear DNA would be Cordilleran. Asymmetries in migration timing between coastal and interior groups and the earlier arrival of males on the breeding ground of the coastal form have been hypothesized to account for similar patterns of cytonuclear discordance in hybrid zones between hermit warblers Dendroica occidentalis and Townsend's warblers Dendroica townsendi (Rohwer et al. 2001), and between two subspecies of Swainson's thrush Catharus ustulatus (Ruegg 2007), both also occurring in the Pacific Northwest.

Asymmetries in mating could be augmented by demographic effects related to the higher densities of Pacific-slope flycatchers. Because the effective population sizes of mitochondrial genes are $1 / 4$ those of nuclear genes (Avise 2004), a mitochondrial haplotype lineage can be lost by chance in a population comparatively easily, especially if initially rare (Ballard and Whitlock 2004). If the frequency of Cordilleran females were low, the much higher density of Pacificslope females in the region coupled with genetic drift could help fix the Pacific-slope haplotype in the Canadian population, especially in the presence of species- and sexbiased differences in arrival times to the breeding grounds.

The genetic similarity of populations west of the Cascades (Vancouver and Hope) and Pacific-slope populations on the coast of California, as well as their almost equal level of divergence from the Cordilleran reference samples, indicate that Canadian populations west of the Cascades are Pacific-slope. The decrease in the level of Cordilleran ancestry evident between the Okanagan and Princeton to some extent may reflect the small sample sizes at these two sites and the presence of two individuals at the Okanagan site with a high proportion of Cordilleran ancestry, but it is notable that the magnitude of change in the proportion of Cordilleran ancestry between Princeton and Okanagan is 
not evident in any other comparison between pairs of neighboring sites, despite comparable sample sizes in some cases. Princeton shows only a very low level of population admixture (one of four individuals sampled was 0.81 Pacific-slope; the remaining three were $\geq 0.90$ Pacificslope). This relatively sharp transition in the level of Cordilleran ancestry suggests that the Cascades may form a western boundary to this hybrid zone.

Our results indicate that there is not a strong reproductive barrier between Pacific-slope and Cordilleran flycatchers in southwestern Canada. The presence of genetically intermediate individuals in an area extending over $400 \mathrm{~km}$ might be suggestive of neutral diffusion resulting from a lack of reproductive isolation rather than a tension zone. On the other hand, the decrease in Cordilleran ancestry at the eastern edge of the Cascades and the occurrence of the highest proportions of Cordilleran nuclear ancestry in the relatively xeric southern interior of $\mathrm{BC}$ suggests that the ecological differences between Pacific-slope and Cordilleran flycatchers may play an important role in limiting areas of sympatry between the two taxa and by extension limiting opportunities for hybridization. If so, the hybrid zone between these two species may be best described by a selection gradient model. However, models suggest that tension zones will tend to move to areas of low population density (Barton and Hewitt 1989) such as occur for these taxa at the Cascades (Campbell et al. 1997). Thus, without further study we cannot conclude that the apparent break in gene flow at the Cascades is a result of ecological selection acting in an area of environmental transition rather than an effect of low population density.

The decision to split the "western flycatcher" into the Pacific-slope flycatcher and Cordilleran flycatcher (American Ornithologists' Union 1989) was made primarily based on studies of the contact zone in California (Johnson 1980, Johnson and Marten 1988), without data from interior southwestern Canada. We now wonder whether, given the present evidence, the decision to formally split the taxa into distinct species would have been made. On one hand, our data indicate that the two taxa hybridize within a broad region of contact, indicating that perhaps they are best treated as a single species. On the other hand, allopatric populations are genetically distinct and differentiated behaviorally, morphologically, and ecologically (Johnson 1980, Johnson and Martens 1988, Johnson and Cicero 2002); hence, they presently remain evolutionary divergent despite the hybridization. We have no evidence that the genetic introgression seen in interior southwestern Canada has affected populations outside of this region. Thus the allopatric populations might continue to remain distinct despite the presence of the hybrid zone. This situation illustrates the challenges involved in species-level taxonomy, as different species definitions contain competing ideas regarding the importance of reproductive isolation versus evolutionary distinctiveness regardless of the potential to hybridize. An accurate assessment of the species status of the "western flycatcher" complex will require detailed studies of the amount and form of any reproductive isolation between the taxa in the contact zone, as well as an analysis of whether the allopatric populations are likely to remain differentiated despite the apparent introgression between them.
Acknowledgements - For financial support, we thank the Natl. Sci. and Eng. Res. Council of Canada (Discovery Grant to DEI). Mol. analysis was conducted in the UBC Lab. for Mol. Biogeog., funded in part by grants to DEI from the Canadian Found. for Innov. and the BC Knowledge Devt. Fund. We thank Environ. Canada for issuing permits (Master Banding Permit 10746, Sci. Permit 59-05-0344 for work in British Columbia, and Sci. Permit CWS05-A003 for work in Alberta), and the Animal Care Comm. of Univ. of British Columbia and Univ. of Calgary for permission to conduct fieldwork. We thank the Mus. of Vert. Zool. for tissue samples. A. Rush thanks D. Toews for lab training, and A. Brelsford for advice in the field, and in the lab. We thank the Rauri Bowie lab, Ricardo Pereira, Sonal Singhal, David Toews, Jay Pitoccheli, and two anonymous reviewers for helpful comments on the manuscript. We thank Verna Bowie for help with the figures and maps.

\section{References}

Ainsley, D. T. J. 1992. Vocalizations and nesting behaviour of the Pacific-slope flycatcher, Empidonax diffcilis. - MSc thesis. Univ. of Victoria, Canada.

American Ornithologists' Union. 1989. Thirty-seventh supplement to the American Ornithologists' Union check-list of North American birds. - Auk 106: 532-538.

Avise, J. C. 2004. Molecular markers, natural history, and evolution. - Sinauer Ass., Sunderland.

Ballard, J. W. and Whitlock, M. C. 2004. The incomplete natural history of mitochondrial DNA. - Mol. Ecol. 13: 729-44.

Barrowclough, G. F. 1980. Genetic and phenotypic differentiation in a wood warbler (genus Dendroica) hybrid zone. - Auk 97: 655-668.

Barton, N. H. and Gale, K. S. 1993. Genetic analysis of hybrid zones. - In: Harrison, R. G. (ed.). Hybrid zones and the evolutionary process. Oxford Univ. Press, New York, pp. 13-45.

Barton, N. H. and Hewitt, G. M. 1981. Hybrid zones and speciation. - In: Atchley, W. R. and Woodruff, D. S. (eds). Evolution and speciation: essays in honor of M. J. D. White. Cambridge Univ. Press, pp. 109-145.

Barton, N. H., and Hewitt, G.M. 1985. Analysis of hybrid zones. - Ann. Rev. Ecol. Syst. 16: 113-148.

Barton, N. H. and Hewitt, G. M. 1989. Adaptation, speciation and hybrid zones. - Nature 341: 497-503.

Bensch, S. and Åkesson, M. 2005. Ten years of AFLP in ecology and evolution: why so few animals? - Mol. Ecol. 14: 28992914.

Bowie, R. C. K., Fjeldså, J., Hackett, S. J. and Crowe, T. M. 2004. Molecular evolution in space and through time: mtDNA phylogeography of the olive sunbird (Nectarina olivaceal obscura) throughout continental Africa. - Mol. Phyl. Evol. 33: $56-74$.

Campbell, R. W., Dawe, N., McTaggart-Cowan, I., Cooper, J., Kaiser, G., McNall, M. and Smith, G.1997. The birds of British Columbia. - UBC Press, Vancouver.

Campbell, D., Duchesne, P., Bernatchez, L. 2003. AFLP utility for population assignment studies: analytical investigation and empirical comparison with microsatellites. - Mol. Ecol. 12: 1979-1991.

Cicero, C. 2004. Barriers to sympatry between avian sibling species (Paridae: Baeolophus) in tenuous secondary contact. - Evolution 58: 1573-1587.

Cicero, C. and Johnson, N. K. 1998. Molecular phylogeny and ecological diversification in a clade of New World songbirds (genus Vireo). - Mol. Ecol. 7: 1359-1370.

Clement, M., Posada, D. and Crandall, K. A. 2000. TCS: a computer program to estimate gene genealogies. - Mol. Ecol. 9: $1657-1659$. 
Corander, J. and Marttinen, P. 2006. Bayesian identification of admixture events using multilocus molecular markers. - Mol. Ecol. 15: 2833-2843.

Corander, J., Marttinen, P., Siren, J., Tang, J. 2008. Enhanced Bayesian modeling in BAPS software for learning genetic structures of populations. - BMC Informatics. 9: 539.

Coyne, J. A. and Orr, H. A. 2004. Speciation. - Sinauer Ass., Inc., Sunderland.

Drovetski, S. V., Zink, R. M., Rohwer, S., Fadeev, I. V., Nesterov, E. V., Karagodin, I., Koblik, E. A. and Red'kin, Y. A. 2004. Complex biogeographic history of a Holarctic passerine. - Proc. R. Soc. B 271: 545-551.

Edwards, S. V., Kingan, S. B., Calkins, J. D., Balakrishnan, C. N., Jennings, W. B., Swanson, W. J. and Sorenson, M. D. 2005. Speciation in birds: genes, geography, and sexual selection. - Proc. Natl. Acad. Sci. U S A 102: 6550-6557.

Endler, J. A. 1977. Geographic variation, speciation, and clines. - Princeton Univ. Press, New Jersey.

Excoffier, L., Laval, G. and Schneider, S. 2005. Arlequin ver. 3.0: An integrated software package for population genetics data analysis. - Evol. Bioinform. Online 1: 47-50.

Falush, D., Stephens, M. and Pritchard, J. K. 2007. Inference of population structure using multilocus genotype data: dominant markers and null alleles. - Mol. Ecol. Not. 7: 574-578.

Fu, Y. X. 1997. Statistical tests of neutrality of mutations against population growth, hitchhiking and background selection. - Genetics 133: 693-709.

García-Moreno, J. 2004. Is there a universal mtDNA clock for birds? - J. Avian Biol. 35: 465-468.

Good, J. M., Hird, S., Reid, N., Demboski, J. R., Steppan, S. J., Martin-Nims, T. R. and Sullivan, J. 2008. Ancient hybridization and mitochondrial capture between two species of chipmunks. - Mol. Ecol. 17: 1313-1327.

Hackett, S. J. 1996. Molecular phylogenetics and biogeography of tanagers in the genus Ramphocelus (Aves). - Mol. Phyl. Evol. 5: 368-382.

Harrison, R. G. 1993. Hybrid zones and the evolutionary process. - Oxford Univ. Press, New York.

Hubbard, J. P. 1969. The relationships and evolution of the Dendroica coronata complex. - Auk 86: 393-432.

Irwin, D. E. 2002. Phylogeographic breaks without geographic barriers to gene flow. - Evolution 56: 2383-2394.

Irwin, D. E., Alström, P., Olsson, U. and Benowitz-Fredericks, Z. M. 2001a. Cryptic species in the genus Phylloscopus (Old World leaf warblers). - Ibis 143: 233-247.

Irwin, D. E., Bensch, S., Irwin, J. H. and Price, T. D. 2005. Speciation by distance in a ring species. - Science 307: 414416.

Irwin D. E., Bensch, S. and Price, T. D. 2001. Speciation in a ring. - Nature 409: 333-337.

Johnson, N. 1963. Biosystematics of sibling species of flycatchers in the Empidonax hammondii-oberholseri-wrightii complex. - Univ. of California Press, Berkeley.

Johnson, N. 1980. Character evolution and evolution of sibling species in the Empidonax difficilis-flavescens complex (Aves: Tyrannidae). - Univ. of California Press, Berkeley.

Johnson, N. K. 1994. Old-school taxonomy versus modern biosystematics: species-level decision in Stelgidopteryx and Empidonax. - Auk 111: 773-780.

Johnson, N. and Cicero, C. 2002. The role of ecologic diversification in sibling speciation of Empidonax flycatchers (Tyrannidae): multigene evidence from mtDNA. - Mol. Ecol. 11: 2065-2081.

Johnson, N. K. and Marten, J. A. 1988. Evolutionary genetics of flycatchers. II. Differentiation in the Empidonax difficilis complex. - Auk 105: 177-191.
Kroodsma, D. 1984. Song of the alder flycatcher (Empidonax alnorum) and the willow flycatcher (Empidonax trailli) are innate. - Auk 101: 13-24.

Kroodsma, D. 1985. Development and use of two song forms by the eastern phoebe. - Wilson Bull. 97: 21-29.

Kroodsma, D. E., Albano, D. J., Houlihan, P. W. and Wells, J. A. 1995. Song development by black-capped chickadees (Parus atricapillus) and Carolina chickadees (P. carolinensis). - Auk 112: 29-43.

Kulba, B. and McGillivray, W. 2000. The distribution and habitat preferences of the "western flycatcher" in Alberta. - [WWW document, $365 \mathrm{~kb}$ ]. URL http://www.pma.edmonton.ab.ca/ vpub/wefl/index.htm

LI-COR Biosciences. 2003. Applications manual: model 4300 DNA analyzer. - LI-COR Biosci., Lincoln.

Lovette, I. J. 2004. Mitochondrial dating and mixed-support for the " $2 \%$ rule in birds". - Auk 121: $1-6$.

Lowther, P. E. 2000. Pacific-slope flycatcher (Empidonax diffcilis) and Cordilleran flycatcher (Empidonax occidentalis). - In: Poole, A. and Gill, F. (eds). The birds of North America, no. 556. The birds of North America, Inc., Philadelphia.

Maddison, D. R. and Maddison, W. P. 2003. MacClade 4: Analysis of phylogeny and character evolution. Version 4.06. - Sinauer Ass., Sunderland.

Marshall, D. B., Hunter, M. G. and Contreras, A. L. 2003. Birds of Oregon. - Oregon State Univ. Press, Corvallis.

Mayr, E. 1942. Systematics and the origin of species - Columbia Univ. Press, New York.

McCarthy, E. M. 2006. Handbook of avian hybrids of the world. - Oxford Univ. Press.

McDonald, J. H. and Kreitman, M. 1991. Adaptive protein evolution at the Adh locus in Drosophila. - Nature. 354: 114 116.

Miller, A. 1956. Ecologic factors that accelerate formation of races and species of terrestrial vertebrates. - Evolution. 10: 262-277.

Moore, W. S. 1977. An evaluation of narrow hybrid zones in vertebrates. - Q. Rev. Biol. 52: 263-277.

Moore, W. S. and Price, J. T. 1993. Nature of selection in the northern flicker hybrid zone and its implications for speciation theory. - In: Harrison, R.G. (ed.). Hybrid zones and the evolutionary process. Oxford Univ. Press, pp. 196-225.

Newton, I. 2003. The speciation and biogeography of birds. - Academic Press, London.

Parish, R., Coupé, R. and Lloyd, D. 1996. Plants of southern interior British Columbia and the inland northwest. - Lone Pine Publ., Vancouver.

Patton, J. L. and Smith, M. F. 1994. Paraphyly, polyphyly, and the nature of species boundaries in pocket gophers (genus Thomomys). - Syst. Biol. 43: 11-26.

Price, T. 2008. Speciation in birds. - Roberts and Co. Publ., Colorado.

Pritchard, J. K., Stephens, M. and Donnelly, P. 2000. Inference of population structure using multilocus genotype data. - Genetics 155: 945-959.

Pyle, P. 1997. Identification guide to North American birds. - Slate Creek Press, California.

R Development Core Team. 2006. R: a language and environment for statistical computing. - R Found. for Stat. Comp., Vienna, Austria. http://www.R-project.org

Rising, J. D. 1996. The stability of the oriole hybrid zone in western Kansas. - Condor 98: 658-663.

Rozas, J., Sánchez-DelBarrio, J. C., Messeguer, X. and Rozas, R. 2003. DnaSP, DNA polymorphism analyses by the coalescent and other methods. - Bioinform. 19: 2496-2497.

Rohwer, S., Bermingham, E. and Wood, C. 2001. Plumage and mitochondrial DNA haplotype variation across a moving hybrid zone. - Evolution 55: 405-422. 
Ruegg, K. 2007. Genetic, morphological, and ecological characterization of a hybrid zone that spans a migratory divide. - Evolution 62: 452-466.

Seutin, G., White, B. N. and Boag, P. T. 1991. Preservation of avian blood and tissue samples for DNA analyses. - Can. J. Zool. 69: 82-90.

Stein, R. C. 1963. Isolating mechanisms between populations of Traill's flycatchers. - Proc. Am. Phil. Soc. 107: 21-50.

Toews, D. P. L. and Irwin, D. E. 2008. Cryptic speciation in a Holarctic passerine revealed by genetic and bioacoustic analyses. - Mol. Ecol. 17: 2691-2705.

Vallender, R., Robertson, R. J., Friesen, V. L. and Lovette, I. J. 2007. Complex hybridization dynamics between goldenwinged and blue-winged warblers (Vermivora chrysoptera and Vermivora pinus) revealed by AFLP, microsatellite, intron and mtDNA markers. - Mol. Ecol. 16: 2017-2029.

Vos, P., Hogers, R., Bleeker, M., Reijans, M., van de Lee, T., Hornes, M., Frijters, A., Pot, J., Peleman, J., Kuiper, M. and
Zabeau, M. 1995. AFLP: A new technique for DNA fingerprinting. - Nucl. Acids Res. 23: 4405-4414.

Wahl, T. R., Tweit, B. and Mlodinow, S. G. (eds). 2005. Birds of Washington. - Oregon State Univ. Press, Corvallis.

Wake, D. B. and Schneider, C. J. 1998. Taxonomy of the Plethodontid salamander genus Ensatina. - Herpetologica 54: 279-298.

Wang, Z., Baker, A. J., Hill, G. E. and Edwards, S. V. 2003. Reconciling actual and inferred population histories in the house finch (Carpodacus mexicanus) by AFLP analysis. - Evolution 57: 2852-2864.

Weir, J. T. and Schluter, D. 2004. Ice sheets promote speciation in boreal birds. - Proc. R. Soc. B 271: 1881-1887.

Weir, J. T. and Schluter, D. 2008. Calibrating the avian molecular clock. - Mol. Ecol. 17: 2321-2328.

Zink, R. M. and Barrowclough, G. F. 2008. Mitochondrial DNA under siege in avian phylogeography. - Mol. Ecol. 17: 21072121. 